\title{
Influence Of The Leaders' Emotionally Intelligent Behaviours On Their Employees' Job Satisfaction
}

Prakash Singh, Nelson Mandela Metropolitan University, South Africa

\begin{abstract}
The ability of leaders to recognise both interpersonal and intrapersonal emotions and then react appropriately will depend on their own level of emotional intelligence (EI). The success of organisational effectiveness is greatly enhanced through the leaders' use of emotionally intelligent competencies which are embodied in their emotionally intelligent behaviours (EIBs). Actually, EIBs are EI actions or reactions that can be observed and measured by others. This exploratory study therefore investigated whether there is a significant correlation between the EIBs of leaders and the job satisfaction of their employees.
\end{abstract}

The survey included a rating by the employees of their leaders' levels of interpersonal and intrapersonal EIBs, and a rating of how each EIB would influence their sense of job satisfaction. Findings emanating from this study strongly suggest that there is a significant correlation between the employees' sense of job satisfaction and their leaders' interpersonal and intrapersonal EIBs. The evidence presented revealed that a leader's EIBS are a form of intrinsic motivation that motivates employees to perform at their optimum levels because they are satisfied in their jobs. Results of this exploratory study connote that the more satisfied employees are at work, the more appropriate their leaders' EIBs would be, as one of the factors in determining the employees' job satisfaction. In contrast, the more dissatisfied employees are at work, the less meaningful their leaders' interpersonal and intrapersonal EIBs could be. Evidently, outstanding leadership EIBs can impact positively on employees' performance delivery and contribute to the creation of a harmonious work environment.

Keywords: Leaders' Emotionally Intelligent Behaviours; Leaders' Interpersonal Skills; Leaders' Intrapersonal Skills; Employees' Job Satisfaction

\section{INTRODUCTION}

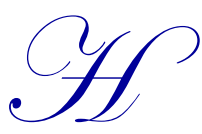

appiness is the key that unlocks the door of job satisfaction for employees. Traditional cognitive intelligence (IQ) should be combined with non-cognitive, emotional intelligence (EI) to empower leaders to perform at their best and inspire employees to be successful and happy (Bazerghi, 2003a). Combining these two competencies can form the foundation for leadership effectiveness, inspirational workers, high levels of achievement and ultimately job satisfaction (Bazerghi, 2003b). To achieve this noble objective in any organisation, the challenge for leadership in the $21^{\text {st }}$ century is to fully internalize the diverse and changing needs of individuals and to create innovative strategies that are employee-driven (Bouchikhi \& Kimberly, 2000). Employees concur that they want to be associated with leaders who are imbued with integrity and trustworthiness, with a vision and a sense of direction, and with enthusiasm and passion (Kouzes \& Posner, 2000; Singh, Manser \& Dali, 2013). Research strongly suggests that emotions can be deemed to be a leader's greatest asset and source of energy in order to create a vision and strategy in the organisation, to build meaningful relationships, and to inspire other people (Goleman, 1998; Stein \& Book, 2001; Noyes, 2003; Dantley, 2005; Singh, Manser, \& Dali, 2013). Kouzes and Posner (1995) aptly assert that: 
If work comes to be seen solely as a source of income and never as a source of fulfilment, organizations will totally ignore other human needs at work - needs involving such intangibles as learning, self-worth, pride, competence, and serving others...work comes from the inside out; work is an expression of our soul, our inner being. Without employing peoples' hearts, organizations lose precious returns on their investment in people. (p.41)

The ability of leaders to recognise both interpersonal and intrapersonal emotions and then react appropriately will depend to a large degree on their own level of EI (Goleman, 1996). The success of organisational effectiveness, therefore, is greatly enhanced through the leader's use of emotionally intelligent techniques and measures (Orme, 2000). These emotionally intelligent techniques are reflected in the emotionally intelligent behaviours (EIBs) of leaders and are referred to by Goleman (1998) as emotional competencies. EIBs refer to those observable actions and reactions that determine one's level of EI or, as Goleman suggests, the level of EI determines the potential for learning the practical skills that create emotional competences or EIBs. If there is a link between the EIBs of a leader and an employee's sense of job satisfaction, then a leader's leadership qualities and observable EIBs could influence an employee's attainment of job satisfaction - this being the main objective of the study. EIBs are EI actions or reactions that can be observed and measured by others (Manser, 2005; Goleman, 1998; Singh, Manser \& Dali, 2013). They can be regarded as either being appropriate or inappropriate. They comprise a number of characteristics that make them identifiable as manifestations of EI and are important measures of a leader's ability to handle others and themselves in a manner that is regarded as compassionate, sensitive and appropriate (Fehd, 2001). They are observed in the interpersonal domain (the appropriateness of a leader's responses and subsequent actions to the emotional signals emanating from others) and in the intrapersonal domain (the appropriateness of a leader's reaction and subsequent behaviour as a result of internal emotions being experienced) (Goleman, 1998; Gardner, 1999; Fehd, 2001; Salovey \& Mayer, 1990).

The process of human endeavour should always be recognized as being equally important as the task at hand and the product to be developed, or the service to be rendered (Garratt, 2000). Therefore, traditional preconceptions held by leaders regarding expected behaviour and role definitions of their employees need to be altered in order to facilitate the concepts of shared decision-making, shared leadership and transformational thinking (Kouzes \& Posner, 2001; Singh, 2005). Leaders may either enhance or retard an employee's sense of job satisfaction depending on the appropriateness of their EIBs (Boyatzis, Goleman \& Rhee, 2000; Goleman, 1998). If EI is the distinguishing factor between great leaders and average leaders, as Cavallo and Brienza (2001) suggest, then the appropriateness of leaders' EIBs should correlate with the success, efficiency, and levels of job satisfaction of employees (Singh, Manser \& Dali, 2013). EI is regarded as a major predictor of leadership success and is described by Sterrett (2000) as that which differentiates exceptional performance from mediocre performance. It is a form of intelligence that comprises a set of non-cognitive abilities in the affective domain that influences one's ability to perceive or sense and understand the emotions of others (interpersonal EI) or to identify and manage one's own emotions (intrapersonal EI) in a manner that elicits appropriate responses and behaviour (Fehd, 2001; Sterrett, 2000). It works synergistically with IQ, rather than separate from it, and it can be measured, learned, and developed (Orme \& Cannon, 2000). It is regarded as a powerful motivational tool as it inspires confidence and trust in leaders who demonstrate high levels of EI (Mayer, Salovey \& Caruso, 2000; Gardner, 1999).

The specific people-centred leadership skills that are necessary for leaders to develop the job satisfaction of employees could be the foundation upon which EIBs displayed by leaders are built (Chowdhury, 2000). When these skills are developed, they could enhance the possibility of employees reaching a sense of job satisfaction. Such leaders are described by Lee (2005) as being emotionally expressive in their behaviour toward others and emotionally stable within themselves. They instil confidence and emotional stability in their followers and motivate them to give of their best (Cherniss \& Adler, 2000). Charismatic influence stems from the leader's personal idiosyncratic power rather than from position of power (Conger \& Kanungo, 1998). The leaders' appropriate interpersonal and intrapersonal EIBs could be crucial to the creation of a motivated and satisfied team of employees in the organisation. Hence, the problem investigated in this study focused on the influence of the leaders' interpersonal and intrapersonal EIBs on the job satisfaction of their employees. 


\section{EMOTIONALLY INTELLIGENT BEHAVIOURS OF LEADERS}

\section{Leaders' Emotional Truths}

Emotional truths translate into trust and create a sense of belongingness, depending on the leaders' ability to identify their own emotions and those of their employees (Levine, 2000). Bouchikhi and Kimberly (2000, p.217) avow that after being pushed to the background by the logic of "scientific management", the centrality of trust in organisational life is being rediscovered. They strongly believe that the challenges of management in the $21^{\text {st }}$ century will require that trust be put at the core of the employment relationship. EI is regarded as the ability to access, use, understand and control one's own emotions and the emotions of other people to achieve desired results (Orme, 2001). EI involves the ability of people to perceive accurately, to appraise and express emotion which, according to Salovey and Sluyter (1997), is the capacity to access and generate feelings when these facilitate thought. It offers the potential to demonstrate what Salovey and Sluyter (1997) describe as the capability to understand emotion and emotional knowledge which allows us to regulate our emotions. In their earlier studies, Salovey and Mayer (1990) aptly conceptualised EI "as the subset of social intelligence that involves the ability to monitor one's own and others' feelings and emotions, to discriminate among them, and to use this information to guide one's thinking and actions." (p.189)

The EIBs of leaders do not only help employees perform more effectively on the job, but they can also contribute to their physical well-being and sense of emotional stability (Goleman, 1998; Dainty \& Anderson, 2000). Leaders need to learn how important emotions are when trying to identify an organization's strengths and weaknesses. This plays a potentially important role in understanding how organizations function. Teaching about emotions and EIBs could affect a team's performance because the members of the team will have a greater understanding about themselves and their colleagues (Goleman, 1998; Bass, 2002; Evans, 2000). Changes that need to be made to leadership structures should not be thought of as a special occasion, but rather as a process of development, change and adaptation (Maxwell, 1993; Spangenberg, 1994). Part of the process of adaptation is inspired by the voice of the human spirit which is described by Covey (2004) as:

... a timeless reality that encompasses the soul of an organization that becomes an integral part of development and change and ultimately passionate involvement in an organization. When you engage in work that taps your talent and fuels your passion that arises out of a great need in the world that you feel drawn by conscience to meet, therein lies your voice, your calling, your soul's code. (p.7)

Leaders cannot simply succeed through intellectual arrogance (Levine, 2000). Codianni, as quoted by Kouzes and Posner (2000), believes that leadership is all about people and he asserts that "Encouraging the heart is the most important leadership practice because it's the most personal" (p.29). Employees' emotions do matter and if they are ignored by leaders, then quality performances will diminish. Emotional truths can be marginalized and blocked out by mean collegial leaders (Singh, 2010). According to Singh (2010), mean collegial leaders demonstrate low levels of EI and collegiality and are autocratic, as well as tobephobic, in decision-making, are prone to tantrums, and can be bad-tempered. Such tobephobic leaders show no compassion and therefore treat fellow workers shabbily and create fear in the work environment (Singh, 2010). Poor leadership EIBs can impact negatively on employees' performance delivery and cause dissatisfaction in the workplace (Pacoe, Ali \& Warne, 2002; Shoho, Merchant \& Lugg, 2005). These are traits often observed in leaders who, according to Goleman (1998, p.287):

- $\quad$ Make decisions that demoralize

- $\quad$ Have difficulty managing creativity and making decisions

- $\quad$ Ignore the crucial value of social skills

- $\quad$ Display an inability to motivate and inspire

- $\quad$ Create hollow mission statements

- $\quad$ Display empty slogans of the day

- $\quad$ Follow leadership by the book

- $\quad$ Lack zest or energy

- $\quad$ Demonstrate drudgery instead of spontaneity 
- $\quad$ Have a lack of esprit de corps

- Ignore teams that don't work

The challenges of fear and anxiety amongst employees arise because, to some extent, everyone experiences fear of making a mistake, as all change efforts in the organisation can induce fear (Senge \& Kaufer, 2000). Deep change processes that call into question long-held beliefs and attitudes and habitual ways of acting (such as deferring to leaders or leaders not having to reveal their reasoning) can be especially threatening to employees (Senge \& Kaufer, 2000). Fear of failure in the organisation can culminate in questions being raised by employees regarding their ability and training to perform at optimum levels and can be the cause of emotional dissonance in the workplace (Senge \& Kaufer, 2000). This fear can result in them suffering from tobephobia which is associated with them being educationally inadequately equipped to do their work (Singh, 2008; Singh, 2011). Creating a fearful atmosphere in the working environment is a major management blunder that can impact negatively on the organisation's vision and mission (Chowdhury, 2000).

Fear can have a dampening effect on employees' job satisfaction as it could negatively impact on their expectations and, consequently, their self-esteem (Singh, 2011). Tobephobic leaders prefer bureaucracy to collegiality (Singh, 2010) and are usually founded on a yes-person culture around them (Evans, 2000). To them, power is enshrined in their position; it is a matter of positional authority instead of authority of expertise identified amongst the employees (Singh, 2010). To build trust and overcome fear, leaders should (Senge \& Kaufer, 2000):

- $\quad$ Avoid frontal assaults on employees' anxieties

- $\quad$ Start small and build momentum before confronting difficult issues

- Deploy new rules and regulations judiciously

- Cultivate openness

- $\quad$ Work to develop a link between vision and reality

- $\quad$ Lay a foundation of common values in the organisation

- $\quad$ Develop specific structures that guard against authoritarian drift

- $\quad$ Promote a coherent philosophy regarding the sources and uses of power - Without clear governing principles, power tends to be exercised in the form of unilateral decisions by executives, reinforcing the perception that it is wielded arbitrarily.

Emotionally intelligent leaders must be able to cope with the paradoxes of leadership as succinctly put forward by Evans (2000, p.75):

- To be able to build a close relationship with one's staff... and to keep a suitable distance

- $\quad$ To be able to lead... and to hold oneself in the background

- $\quad$ To trust one's staff... and to keep an eye on what is happening

- To be tolerant... and to know how you want things to function

- $\quad$ To be a visionary... and to keep one's feet on the ground

- To be dynamic... and to be reflective

At the heart of leadership is the ability to set goals and directions with a vision that is also owned by every employee in the organisation (Evans, 2000). Leaders need to be sensitive to the need for change on the one hand and empathise with how employees feel about what they are expected to do on the other. There is a dire need to have an understanding of emotional grammar and an ability to identify emotions in employees and themselves as leaders (Vermeulen, 1999). A high staff turnover is experienced in organisations where leaders convey negative feelings to their staff as their sense of meaningful collaboration and sincere community identity are in doubt and hence, they are not trusted by the workforce (Liddy, 2013; Evans, 2000; Levine, 2000).

The commitments of leaders to create meaningful shared leadership structures are enhanced by what Bass (2002) describes as four behaviours that require emotional, yet reasoned, appeals:

- Idealized influence is a behaviour that arouses emotions and identification with the leader

802 Copyright by author(s) Creative Commons License CC-BY

2013 The Clute Institute 
- Intellectual stimulation increases awareness of problems and influences people to look at problems from a positive perspective

- $\quad$ Individualized consideration includes providing support, encouragement, and coaching to followers

- Inspirational motivation models appropriate behaviours on the organization's vision, mission and core values.

In order to attain planned organisational objectives, Chowdhury (2000) suggests that leaders should become peoplistic instead of being individualistic. Any organisation can have the best communication system, but if a leader is solely individualistic as a firm believer of bureaucratic measures, then the organisation can suffer. Why? Communication can fail due to impregnable layers of bureaucracy. As pointed out by Chowdhury (2000), effective communication helps to break down traditional organisational hierarchy and it also encourages communication of good and bad news. Peoplistic communication must become a priority for the $21^{\text {st }}$ century emotionally intelligent leader if the happiness and job satisfaction of employees are to be part of the organisation's vision, mission, and core values.

In her article titled Empathy: A Gateway to Objectivity, Birchfield (2013) affirms that:

Empathy is the linchpin between compassion, which arises from the heart, and understanding, which arises from the mind. There is no understanding of others without compassion. So, too, there is no compassion without understanding. When we perceive others without compassion, judgment arises. We usually assume that we are an impartial judge. However, to be truly impartial requires understanding. True understanding is informed by empathy. As we respond with empathy, compassion inevitably arises. This doesn't mean that our judgment is clouded by emotion, but rather that it is informed by emotion. (p.1)

Leaders are expected to develop their empathic capacity so that their employees' needs and concerns are understood. Empathy serves as a gateway to understanding and compassion and, therefore, emotionally intelligent leaders would not plough through and impose their agendas, leaving their employees demoralized and angry (Birchfield, 2013). A 21st century organization should be characterized by collaborative teamwork practices because it should have shifted its emphasis from the management of tasks to the leadership of people. This view is supported when one accepts that leadership involves the creation of multi-partnerships, the success of which is embedded in the quality of relationships that function as inclusive, motivated units. In order for the collaborative units being functional, people need to be led with confidence and leaders need to have a clear understanding of the needs and the emotional strengths and weaknesses of those who are to be led (Singh, Manser \& Dali, 2013).

Leaders must understand empathetically what the fears and needs of employees are and where their strengths and weaknesses lie (Stein \& Book, 2001). They need to comprehend that employees display a variety of emotions that should be handled with professional sensitivity. Interpersonal and intrapersonal EIBs should be put into practice in order to improve the leaders' ability to handle ever-changing situations and they should be flexible to choose a suitable behaviour for the appropriate situation. When leadership structures are built around the empowerment of individuals and the active involvement of all employees, the best long-term efficiency is achieved. Most employees want to feel confident in their jobs and know that by being empowered, they are making meaningful contributions to the effectiveness of their organisations (Du Plessis, Bouwer \& Eloff, 2002). Empathy and compassion are the nucleus of collaboration and empowerment because without them, human feelings and emotions are ignored and employees then begin to stray from the organization's core purpose because they are unhappy, as pointed out by Cooper and Sawaf (1997):

It is from empathy, especially when there is an environment of trust, that connection comes, one person to another. In terms of corporate and career achievements, it can be said that almost everything begins and ends in the emotions of confident relationships, in human connectedness. (p.53)

\section{Job Satisfaction Of Employees}

Job satisfaction can be defined as an emotional state of either liking or disliking one's job because of a global feeling on the one hand, or a set of related attitudes that are caused by aspects of the job that produce either satisfaction or dissatisfaction on the other (Strümpfer \& Mlonzi, 2001). It would be naïve to believe that one can 
simply divide the world of work into two distinct scenarios, where employees are identified as either unhappy and unproductive, or happy and productive (Manser, 2005). If this were the case, then one could offer a basic recipe with a list of ingredients for improving job satisfaction. It may also be so that happiness and productivity do not necessarily form an automatic alliance, but rather there are a number of other factors that are said to influence the creation of job satisfaction (Singh, Manser \& Dali, 2013). There seems to be little doubt that organizations that have sustainable successes are those that manage to motivate their people effectively. These organizations are able to maximize the potential of their human resources by recruiting the most suitable candidates, enabling them through relevant induction and mentor programmes, and motivating them to work at optimum performance levels (Yun, 1998). A longitudinal study conducted by labour economists in Ohio State, in the USA revealed that job satisfaction or dissatisfaction continued, even when people changed their places of work (Staw, 1996) This evidence of consistency supports the hypothesis that if one is dissatisfied in one kind of job context, one is likely to be dissatisfied with another, even if the environment is better. If specific beliefs and expectations pertaining to the job are not met, then the result could be that an employee will remain dissatisfied until the misconceptions are resolved.

Leaders need to demonstrate the necessary emotional leadership skills in order to understand and assist in the creation of job satisfaction and positive attitudes amongst employees (Stein \& Book, 2001; Sterrett, 2000). In order for organisations to be more desirable places in which to work, it is necessary for leaders to recognise their employees' emotions, be sensitive to their needs and be able to identify the EIBs they need to use in order to be successful leaders (Goleman, 1998). They need to have knowledge of their own capabilities and limitations and be able to identify the factors and situations that evoke emotion at both interpersonal and intrapersonal levels. If a leader is able to do this, then Goleman (1998) claims that the control and understanding of emotions and behaviours of oneself and others could improve vastly. The leader's ability to understand, identify and empathise with employees' emotions and then react appropriately are, according to Goleman (1996), integral factors which could help foster a feeling of job satisfaction amongst employees:

Those who are emotionally intelligent can connect with people quite smoothly, be astute in reading their reactions and feelings, lead and organise, and handle disputes that are bound to flare up. They are the natural leaders, the people who can express the unspoken collective sentiment and articulate it so as to guide a group towards its goals. They are emotionally nourishing - they leave people in a good mood. (p.119)

If one agrees that the human element in an organization needs to develop along with the pace of change, then Sharon, Latour, Bradley and Hosmer (2002) argue that people - and not products - are the most important resource which necessitates that leaders focus on the intrinsic needs of people in order to discover what makes them satisfied at work. Leaders need to create professional relationships with employees in order to create mentoring roles that develop partnerships and modify behaviours that are necessary to improve the EIBs of team members. The Japanese belief that work is a means of demonstrating one's abilities and aptitudes so that the whole organization may benefit, has its roots in intrinsic compensation or a sense of moral gratification (Singh, Manser \& Dali, 2013). A leader's influence should be based on the intrinsic characteristics of consistency, values, inspiration and commitment. According to Hoppe \& Speck (2003), if leaders at the top of an organisation demonstrate consistent values over a long period of time, then employees will most likely demonstrate these values as well. Cherniss and Adler (2000) proposed a model for promoting EI in the workplace that could impact on the job satisfaction of employees through the creation of intrinsic worth which they divided into a process of four phases:

1. The Securing Of Organizational Support: This involves the employment of emotionally intelligent leaders, the creation of autonomy in decision-making structures, linking EI to the needs of the organization, and introducing training to improve the EI of staff.

2. Preparing For Change: The importance of self-directed learning is stressed and includes the setting of clear manageable goals and the creation of positive expectations amongst employees.

3. Training And Development: The recognition and acknowledgement of emotions is a skill that is learned during this phase. How to deal with extreme emotions is also paramount. The development of a positive relationship between the leader and the employee is important in this phase.

4. Encouraging, Maintaining And Evaluating Change: The leader's role in providing ongoing encouragement and support is vital here. The role of a mentor should be assumed and ongoing evaluation of emotional development should be made. (p.66) 
The model provides a useful framework for designing an intervention programme to help develop leaders' interpersonal and intrapersonal competencies and should assist employees in reaching a feeling of satisfaction at work that, in turn, enhances organizational development (Hayward, 2003). It also supports the belief that team trust, cooperation, motivation and collaboration, results from an effective control of emotions which facilitates a positive working environment (Kochan \& Reed, 2005). An emphasis on intrinsic motivation will also encourage a move away from measurement according to the objectives and performance ratings, a system of assessment that receives negative responses from many employees (Spangenberg, 1994).

Leaders who demonstrate outstanding leadership qualities display a high level of positive energy that tends to spread through their organizations. EIBs are positively related to the leaders' ability to be innovative and creative in the workplace and emotion control correlates positively with their ability to work with employees as team members toward the success of the organization. In order for employees to reach a level of job satisfaction that produces high levels of efficiency and effectiveness, it is imperative for leaders to demonstrate very specific EIBs and leadership skills as pointed out by Gardner and Stough (2002):

The ability of the leader to be able to identify and understand the emotions of others in the workplace, to be able to manage their own and others' positive and negative emotions, to be able to control emotions in the workplace effectively, to utilize emotional information when problem solving and to be able to express their feelings to others is integral to the leader being effective at creating appropriate levels of job satisfaction. (p.76)

There is a link between organizational commitment - in other words the strength of the employees' identification with the organization - and job satisfaction. The link indicates that there is strong support for and an acceptance of the organization's goals and values and, as a result, employees are willing to offer high levels of commitment, service, and loyalty to the organization because they are satisfied at work. Leaders need to understand, therefore, that there should be a direct link between organizational commitment, the level of efficiency that is required from all employees, and a presence of job satisfaction in order for an organization to attain its objectives (Singh, Manser \& Dali, 2013). For this to materialise, it is imperative for leaders to demonstrate acceptable levels of EIBs in their organisations. Admittedly, organizational commitment has its focus on a more global, long-term attachment to the organization as a whole, as well as an emphasis on congruence between the goals of the individual and those of the organization. The more positive the leaders' strategies, the more helpful, cooperative and positive are those on the team and the ability of leaders to manage their interpersonal and intrapersonal EIBs as predictors of job satisfaction and organizational commitment (Gardner \& Stough, 2003). Inevitably, a leader who deals with and understands emotions in the workplace will assist in the creation of job satisfaction because employees will feel that they are being recognized as individuals and that their feelings and emotions are being deservedly acknowledged.

\section{RESEARCH DESIGN}

The quantitative research method was used to determine the employees' perceptions of their leaders' EIBs. A sample of 474 employees from 200 organizations participated in this study. The subjects chosen to participate in the study were selected following a process described by McMillan and Schumacher (2001) as non-probability convenience sampling because the group of subjects was selected on the basis of their accessibility and availability in South Africa. A multi-respondent survey design was used. In such a design, the focus is on relationships between and among variables in a single group (Robson, 2002; Manser, 2005; Singh \& Manser, 2008; Singh, Manser \& Dali, 2013).

Section A of the survey focused on the demographic variables of the participants while section B collected data on their job satisfaction. Twelve items in the questionnaire (sections $\mathrm{C}$ and $\mathrm{D}$ ) requested that respondents rate their leaders' characteristics of observable EIBs in the interpersonal and intrapersonal domains. In section C, the questionnaire identified six (C1-C6) interpersonal skills that the respondents' employers should possess as leaders. These are: leadership (C1), communication (C2), conflict management (C3), relationships (C4), empathy (C5), and trust (C6). The 55 questions posed asked the respondents to rate their leaders according to the strength of the observable interpersonal EIBs. Section D identified six (D1-D6) intrapersonal EIBs that the respondents' leader should possess. These are self-awareness (D1), confidence (D2), self-expression (D3), self-control (D4), adaptability (D5), and optimism (D6). The 56 questions posed asked the respondents to rate their leaders according to the 
strength of each of the observable intrapersonal EIB characteristics. Section E listed a leader's possible EIBs that are identified in sections $\mathrm{C}$ and $\mathrm{D}$. The respondents were asked to rate the $12 \mathrm{EIBs}$ according to the influence that each had on their sense of job satisfaction as employees.

The value of Cronbach's Alpha was used to determine the reliability of the research; it verified that the research was reliable, that the questionnaire was consistent, and the scores had insignificant error. The score of 0.923 for the overall reliability of sections B, C, and D was regarded as significant. Also, in order to ensure the content and construct validity of the questionnaire, a study of relevant literature on EI was undertaken. As part of the literature study for the research, the following models of EI were critically analysed to compile the questionnaire:

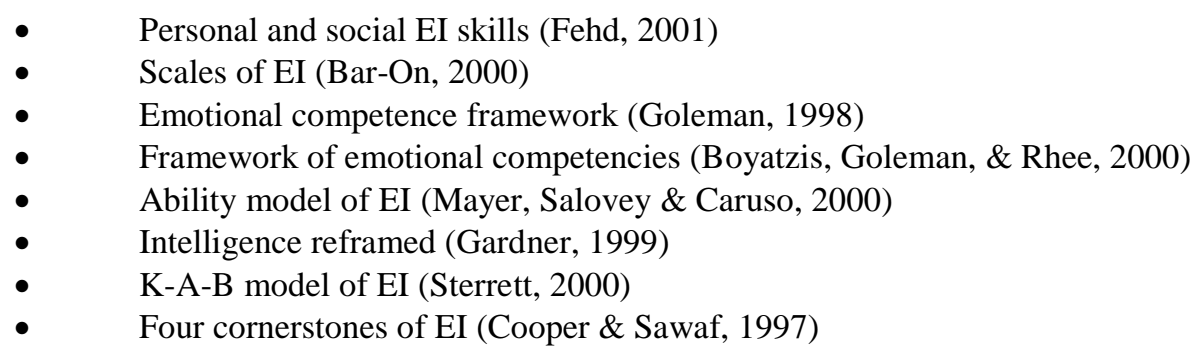

These models of EI divide EI into skills, scales, competencies, abilities, traits, dimensions, behaviours and cornerstones. Although the models are unique in certain aspects, there are significant similarities that exist. This process facilitated the identification of the twelve generic interpersonal (C1-C6) and intrapersonal (D1-D6) skills used in drawing up the questionnaire.

\section{RESULTS}

A total of 474 responses were used in this quantitative exploratory study to analyse the influence of the leaders' EIBs on the job satisfaction of employees. The statistical details are presented in Tables 1-8. Two measures of relationship were used; namely, the Pearson product - moment correlation $(r)$ and Spearman rank ( $\rho$ or rho). The calculation of $r$ is to show the linear relationship between any two of the variables. According to Huysamen (1997), the calculation of $r$ and $\rho$ provides an objective measure of the strength of the relationship between the two variables. The level of significance for a two-tail test is 0.01. It is pointed out by McMillan and Schumacher (2001) that the degree to which subjects maintain the same relative position on any two measures is shown by $\rho$. In other words, $\rho$ shows how much agreement exists between each of the variables that are listed. For each pair of variables, the coefficient of correlation value, the significance level, and the number of cases $(\mathrm{N})$ is given. The correlation coefficients were calculated to show the relationship between the variables (measures) of job satisfaction attainment (B), the rating of all of the interpersonal EIBs of leaders (C), the rating of all of the intrapersonal EIBs of leaders (D), and the influences that the respondents identify of a leader's EIBs that influenced their sense of job satisfaction (E).

\section{Interpersonal EIBs}

Table 1 presents the Pearson Correlation Coefficients $(r)$ of the variables: job satisfaction (B) and all of the interpersonal EIBs (C1-C6). According to Huysamen (1997), the positive relationship indicated in Pearson's ( $r$ ) @ p $<0.01$ is significant. The Pearson correlation values are greater than zero, indicating a positive correlation between the interpersonal EIBs and the job satisfaction of employees. When there is an increase in C, B will also increase. This indicates that a significant relationship exists amongst the variables; namely, the interpersonal EIBs of leaders (C) and the job satisfaction of employees (B). For example, the Pearson correlation between C4 (relationships) and $\mathrm{B}$ (job satisfaction) is 0.537 with a highly significant p-value of 0 which is less than 0.01 . Of the total number of respondents, 337 of them ranked their leader as being high (strong) in the relationship behaviour and 137 ranked their leader as being low (weak). This indicates that a significant relationship exists between $\mathrm{C} 4$ and $\mathrm{B}$, hence suggesting quite a strong relationship between the relationships behaviour $(\mathrm{C} 4)$ of the leader and the job satisfaction of employees (B). 
Table 1: Pearson Correlation Coefficients For B And C1 - 6

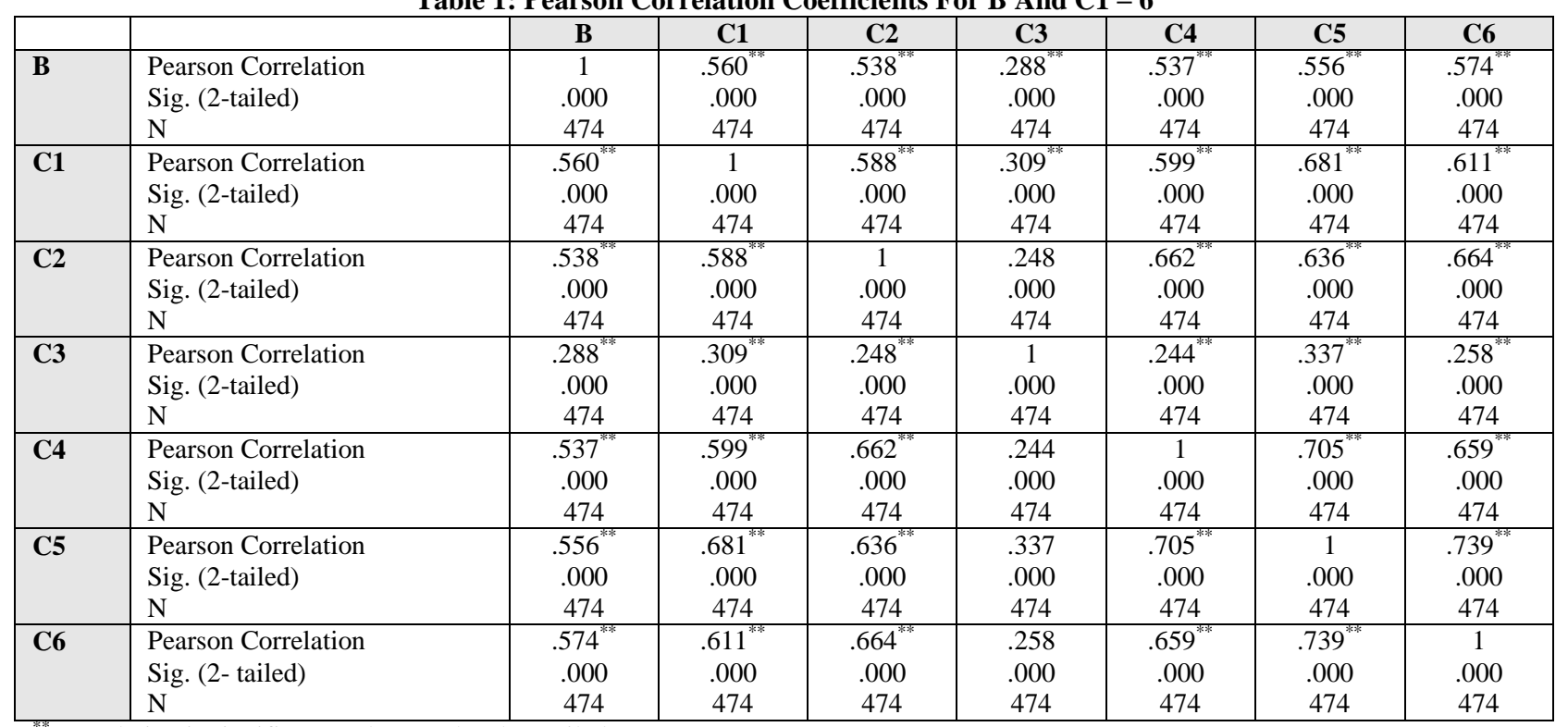

Correlation is significant at the 0.01 level (2-tailed).

Table 2 presents the findings of the Spearman Rank Correlation ( $\rho$ or rho) used to show the symmetric measures and the relationships between the variables job satisfaction (B) and all of the interpersonal EIBs (C1-C6). According to Huysamen (1997), the positive relationship indicated in Spearman's @ p $<0.01$ is significant. The Spearman's correlation values are greater than zero, indicating a positive correlation between the variables. This indicates that a significant relationship exists amongst the variables. The correlation between C3 (conflict management) and $\mathrm{C} 1$ (leadership) is .309 with a highly significant p-value of 0 which is less than 0.01 . This indicates that a significant relationship exists between $\mathrm{C} 3$ and $\mathrm{C} 1$. The Pearson correlation between C6 (trust) \& C5 (empathy) is 0.739 with a highly significant $\mathrm{p}$-value of 0 , which is less than 0.01 . This indicates that a significant relationship exists between $\mathrm{C} 6$ and $\mathrm{C} 5$. There is a large correlation between $\mathrm{C} 3$ and $\mathrm{C} 4$, suggesting a strong relationship between conflict management and the relationship behaviour of the leader.

Table 2: Spearman's Correlation Coefficients For B And C1 - 6

\begin{tabular}{|c|c|c|c|c|c|c|c|c|}
\hline & & B & C1 & $\mathrm{C} 2$ & C3 & C4 & C5 & C6 \\
\hline B & $\begin{array}{l}\text { Correlation Coefficient } \\
\text { Sig. (2-tailed) } \\
\text { N }\end{array}$ & $\begin{array}{c}1 \\
.000 \\
474\end{array}$ & $\begin{array}{l}.560 \\
.000 \\
474\end{array}$ & $\begin{array}{l}.538^{* * 1} \\
.000 \\
474\end{array}$ & $\begin{array}{l}.288^{*} \\
.000 \\
474\end{array}$ & $\begin{array}{l}.537^{* *} \\
.000 \\
474\end{array}$ & $\begin{array}{l}.556 \\
.000 \\
474\end{array}$ & $\begin{array}{l}.574 \\
.000 \\
474\end{array}$ \\
\hline C1 & $\begin{array}{l}\text { Correlation Coefficient } \\
\text { Sig. (2-tailed) } \\
\text { N }\end{array}$ & $\begin{array}{l}.560^{* *} \\
.000 \\
474 \\
\end{array}$ & $\begin{array}{c}1 \\
.000 \\
474 \\
\end{array}$ & $\begin{array}{l}.588^{* * 1} \\
.000 \\
474 \\
\end{array}$ & $\begin{array}{l}.309^{* *} \\
.000 \\
474\end{array}$ & $\begin{array}{l}.599^{* * 7} \\
.000 \\
474 \\
\end{array}$ & $\begin{array}{l}.681^{* \pi} \\
.000 \\
474 \\
\end{array}$ & $\begin{array}{c}.611^{* * * * *} \\
.000 \\
474 \\
\end{array}$ \\
\hline C2 & $\begin{array}{l}\text { Correlation Coefficient } \\
\text { Sig. (2-tailed) } \\
\text { N }\end{array}$ & $\begin{array}{l}.538^{* *} \\
.000 \\
474 \\
\end{array}$ & $\begin{array}{l}.588 \\
.000 \\
474 \\
\end{array}$ & $\begin{array}{c}1 \\
.000 \\
474\end{array}$ & $\begin{array}{l}.248 \\
.000 \\
474\end{array}$ & $\begin{array}{l}.662^{* 2} \\
.000 \\
474 \\
\end{array}$ & $\begin{array}{l}.636^{*+1} \\
.000 \\
474 \\
\end{array}$ & $\begin{array}{l}.664^{* *} \\
.000 \\
474\end{array}$ \\
\hline C3 & $\begin{array}{l}\text { Correlation Coefficient } \\
\text { Sig. (2-tailed) } \\
\text { N }\end{array}$ & $\begin{array}{l}.288^{* *} \\
.000 \\
474\end{array}$ & $\begin{array}{l}.309^{* *} \\
.000 \\
474\end{array}$ & $\begin{array}{l}.248^{* * 1} \\
.000 \\
474\end{array}$ & $\begin{array}{c}1 \\
.000 \\
474\end{array}$ & $\begin{array}{l}.244^{* *} \\
.000 \\
474\end{array}$ & $\begin{array}{l}.337^{* *} \\
.000 \\
474\end{array}$ & $\begin{array}{l}.258^{* *} \\
.000 \\
474\end{array}$ \\
\hline C4 & $\begin{array}{l}\text { Correlation Coefficient } \\
\text { Sig. (2-tailed) } \\
\text { N }\end{array}$ & $\begin{array}{l}.537^{* * 1} \\
.000 \\
474\end{array}$ & $\begin{array}{l}.599^{* *} \\
.000 \\
474\end{array}$ & $\begin{array}{c}.662^{* *} \\
.000 \\
474\end{array}$ & $\begin{array}{c}.244^{*} \\
.000 \\
474\end{array}$ & $\begin{array}{c}1 \\
.000 \\
474\end{array}$ & $\begin{array}{l}.705^{* *} \\
.000 \\
474\end{array}$ & $\begin{array}{l}.659^{*} \\
.000 \\
474\end{array}$ \\
\hline C5 & $\begin{array}{l}\text { Correlation Coefficient } \\
\text { Sig. (2-tailed) } \\
\text { N }\end{array}$ & $\begin{array}{l}.556^{* *} \\
.000 \\
474 \\
\end{array}$ & $\begin{array}{l}.681^{* *} \\
.000 \\
474 \\
\end{array}$ & $\begin{array}{l}.636^{* *} \\
.000 \\
474 \\
\end{array}$ & $\begin{array}{l}.337^{* *} \\
.000 \\
474 \\
\end{array}$ & $\begin{array}{l}.705^{* *} \\
.000 \\
474 \\
\end{array}$ & $\begin{array}{c}1 \\
.000 \\
474 \\
\end{array}$ & $\begin{array}{l}.739^{* * *} \\
.000 \\
474\end{array}$ \\
\hline C6 & $\begin{array}{l}\text { Correlation Coefficient } \\
\text { Sig. (2- tailed) } \\
\text { N }\end{array}$ & $\begin{array}{l}.574^{* *} \\
.000 \\
474\end{array}$ & $\begin{array}{l}.611^{*} \\
.000 \\
474\end{array}$ & $\begin{array}{l}.664^{* * 1} \\
.000 \\
474\end{array}$ & $\begin{array}{l}.258^{* *} \\
.000 \\
474\end{array}$ & $\begin{array}{l}.659^{* *} \\
.000 \\
474\end{array}$ & $\begin{array}{l}.739^{* *} \\
.000 \\
474\end{array}$ & $\begin{array}{c}1 \\
.000 \\
474\end{array}$ \\
\hline
\end{tabular}

Correlation is significant at the 0.01 level (2-tailed). 
The correlation coefficients given in Tables 1 and 2 clearly show that the bivariate distribution of the variables has a positive and direct relationship. Both Pearson $r$ and Spearman $\rho$ indicate that the two variables, namely the job satisfaction of employees and the interpersonal EIBs of a leader rated by the respondents, are significant and therefore directly related. In other words, the findings of this study confirm that the more satisfied an employee is at work the higher a leader's interpersonal EIBs are likely to be. Conversely the more dissatisfied an employee is at work the lower a leader's interpersonal EIBs are likely to be. However, this data must be interpreted in terms of the EIBs of leaders as being one of the major factors affecting the job satisfaction of employees. The noticeable exception is the low positive value for C3 (a leader's ability to handle conflict). However, there is no objective explanation for this particular EIB to be so different from the rest.

\section{Intrapersonal EIBs}

The Spearman Correlation ( $\rho$ or rho) of the variables job satisfaction (B) and the intrapersonal EIBs (D1D6) are presented in Table 3.

Table 3: Pearson Correlation Coefficients For B And D1 - 6

\begin{tabular}{|c|c|c|c|c|c|c|c|c|}
\hline & & B & D1 & D2 & D3 & D4 & D5 & D6 \\
\hline B & $\begin{array}{l}\text { Pearson Correlation } \\
\text { Sig. (2-tailed) } \\
\mathrm{N}\end{array}$ & $\begin{array}{c}1 \\
.000 \\
474 \\
\end{array}$ & $\begin{array}{l}.572^{* * *} \\
.000 \\
474\end{array}$ & $\begin{array}{l}.636^{* * *} \\
.000 \\
474\end{array}$ & $\begin{array}{l}.602^{* *} \\
.000 \\
474\end{array}$ & $\begin{array}{l}.524^{* * *} \\
.000 \\
474\end{array}$ & $\begin{array}{l}.556^{* *} \\
.000 \\
474\end{array}$ & $\begin{array}{l}.595^{* *} \\
.000 \\
474\end{array}$ \\
\hline D1 & $\begin{array}{l}\text { Pearson Correlation } \\
\text { Sig. (2-tailed) } \\
\mathrm{N}\end{array}$ & $\begin{array}{l}.572^{* * /} \\
.000 \\
474\end{array}$ & $\begin{array}{c}1 \\
.000 \\
474\end{array}$ & $\begin{array}{l}748^{* * *} \\
.000 \\
474 \\
\end{array}$ & $\begin{array}{l}.667^{* * 2} \\
.000 \\
474\end{array}$ & $\begin{array}{l}.603^{\text {**F }} \\
.000 \\
474\end{array}$ & $\begin{array}{l}.600^{* * 3} \\
.000 \\
474 \\
\end{array}$ & $\begin{array}{l}.657^{3 * \pi} \\
.000 \\
474\end{array}$ \\
\hline D2 & $\begin{array}{l}\text { Pearson Correlation } \\
\text { Sig. (2-tailed) } \\
\mathrm{N}\end{array}$ & $\begin{array}{l}.636^{* * *} \\
.000 \\
474 \\
\end{array}$ & $\begin{array}{l}.748^{* * *} \\
.000 \\
474 \\
\end{array}$ & $\begin{array}{c}1 \\
.000 \\
474 \\
\end{array}$ & $\begin{array}{l}.663 \\
.000 \\
474 \\
\end{array}$ & $\begin{array}{l}.613^{* *} \\
.000 \\
474 \\
\end{array}$ & $\begin{array}{l}.652^{* *} \\
.000 \\
474 \\
\end{array}$ & $\begin{array}{l}.660^{* * *} \\
.000 \\
474 \\
\end{array}$ \\
\hline D3 & $\begin{array}{l}\text { Pearson Correlation } \\
\text { Sig. (2-tailed) } \\
\mathrm{N}\end{array}$ & $\begin{array}{l}.602^{* * k} \\
.000 \\
474 \\
\end{array}$ & $\begin{array}{l}.667^{* * 6} \\
.000 \\
474 \\
\end{array}$ & $\begin{array}{l}.663^{* * *} \\
.000 \\
474 \\
\end{array}$ & $\begin{array}{c}1 \\
.000 \\
474 \\
\end{array}$ & $\begin{array}{l}.643^{\text {**/ }} \\
.000 \\
474 \\
\end{array}$ & $\begin{array}{l}.610^{* * *} \\
.000 \\
474 \\
\end{array}$ & $\begin{array}{l}.709^{* * *} \\
.000 \\
474 \\
\end{array}$ \\
\hline D4 & $\begin{array}{l}\text { Pearson Correlation } \\
\text { Sig. (2-tailed) } \\
\mathrm{N}\end{array}$ & $\begin{array}{l}.524^{* * k} \\
.000 \\
474 \\
\end{array}$ & $\begin{array}{l}.603^{* * k} \\
.000 \\
474 \\
\end{array}$ & $\begin{array}{l}.613^{* * *} \\
.000 \\
474\end{array}$ & $\begin{array}{l}.643^{* * *} \\
.000 \\
474\end{array}$ & $\begin{array}{c}1 \\
.000 \\
474\end{array}$ & $\begin{array}{l}.648^{* * *} \\
.000 \\
474\end{array}$ & $\begin{array}{l}.633^{* * *} \\
.000 \\
474\end{array}$ \\
\hline D6 & $\begin{array}{l}\text { Pearson Correlation } \\
\text { Sig. (2- tailed) } \\
\mathrm{N}\end{array}$ & $\begin{array}{l}.595^{* * \pi} \\
.000 \\
474\end{array}$ & $\begin{array}{l}.657^{\text {अF }} \\
.000 \\
474\end{array}$ & $\begin{array}{l}.660^{* * *} \\
.000 \\
474\end{array}$ & $\begin{array}{l}.709^{* * 6} \\
.000 \\
474\end{array}$ & $\begin{array}{l}.633^{\text {**/ }} \\
.000 \\
474\end{array}$ & $\begin{array}{l}.725^{\Re *} \\
.000 \\
474\end{array}$ & $\begin{array}{c}1 \\
.000 \\
474\end{array}$ \\
\hline
\end{tabular}

Correlation is significant at the 0.01 level (2-tailed).

Table 3 presents the findings of the Pearson's Product Moment Coefficient used to show the symmetric measures and the relationships between the variables. According to Huysamen (1997), the positive relationship indicated in Pearson's $\mathrm{r} @ \mathrm{p}<0.01$, as shown in Table 3, can be regarded as being significant. The Pearson correlation values, as indicated in Table 3 , are greater than 0 , indicating a positive correlation between the variables $\mathrm{B}$ and D1-6. Thus, a significant relationship exists amongst the variables. The Pearson correlation values are within the range of 0.50 to 1.0 , suggesting a strong relationship between the variables B and D1-D6. Therefore, a significant relationship exists between the variables with a highly significant $\mathrm{p}$ - value of 0 , which is less than 0.01 . For example, the Pearson correlation between D2 (confidence) and B (job satisfaction) is 0.636 with a highly significant p-value of 0 , which is less than 0.01 . Of the total number of respondents, 324 of them ranked their leader as being strong in confidence behaviour and 150 ranked their leader as being weak. This indicates that a significant relationship exists between D2 and B, hence suggesting quite a strong relationship between the confidence behaviour of the leader and the job satisfaction of employees.

The Spearman $\rho$ or rho correlation of the variables job satisfaction (B) and the intrapersonal EIBs (D1-D6) are presented in Table 4. 
Table 4: Spearman's Correlation coefficients $\rho$ For B And D1 - 6

\begin{tabular}{|c|c|c|c|c|c|c|c|c|}
\hline & & B & D1 & D2 & D3 & D4 & D5 & D6 \\
\hline B & $\begin{array}{l}\text { Correlation Coefficient } \\
\text { Sig. (2-tailed) } \\
\mathrm{N}\end{array}$ & $\begin{array}{c}1 \\
.000 \\
474\end{array}$ & $\begin{array}{l}.572^{* *} \\
.000 \\
474\end{array}$ & $\begin{array}{l}.636^{* * *} \\
.000 \\
474\end{array}$ & $\begin{array}{l}.602^{* * *} \\
.000 \\
474\end{array}$ & $\begin{array}{l}.524^{* * *} \\
.000 \\
474\end{array}$ & $\begin{array}{l}.556^{* * *} \\
.000 \\
474\end{array}$ & $\begin{array}{l}.595^{* *} \\
.000 \\
474\end{array}$ \\
\hline D1 & $\begin{array}{l}\text { Correlation Coefficient } \\
\text { Sig. (2-tailed) } \\
\mathrm{N}\end{array}$ & $\begin{array}{l}.572^{* * *} \\
.000 \\
474 \\
\end{array}$ & $\begin{array}{c}1 \\
.000 \\
474 \\
\end{array}$ & $\begin{array}{l}.748^{* * *} \\
.000 \\
474\end{array}$ & $\begin{array}{l}.667^{\text {** }} \\
.000 \\
474\end{array}$ & $\begin{array}{l}.603^{\text {*** }} \\
.000 \\
474\end{array}$ & $\begin{array}{l}.600^{* * *} \\
.000 \\
474\end{array}$ & 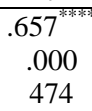 \\
\hline D2 & $\begin{array}{l}\text { Correlation Coefficient } \\
\text { Sig. (2-tailed) } \\
\mathrm{N}\end{array}$ & $\begin{array}{l}.636^{* * *} \\
.000 \\
474 \\
\end{array}$ & $\begin{array}{l}.748^{* * *} \\
.000 \\
474 \\
\end{array}$ & $\begin{array}{c}1 \\
.000 \\
474 \\
\end{array}$ & $\begin{array}{l}.248^{* * *} \\
.000 \\
474 \\
\end{array}$ & $\begin{array}{l}.613^{* * *} \\
.000 \\
474 \\
\end{array}$ & $\begin{array}{l}.652^{* * *} \\
.000 \\
474 \\
\end{array}$ & $\begin{array}{c}.660^{* * *} \\
.000 \\
474 \\
\end{array}$ \\
\hline D3 & $\begin{array}{l}\text { Correlation Coefficient } \\
\text { Sig. (2-tailed) } \\
\mathrm{N}\end{array}$ & $\begin{array}{l}.602^{* * *} \\
.000 \\
474 \\
\end{array}$ & $\begin{array}{l}.667^{\text {** }} \\
.000 \\
474 \\
\end{array}$ & $\begin{array}{l}.663^{* * *} \\
.000 \\
474\end{array}$ & $\begin{array}{c}1 \\
.000 \\
474\end{array}$ & $\begin{array}{l}.643^{\text {*** }} \\
.000 \\
474\end{array}$ & $\begin{array}{l}.610^{* * *} \\
.000 \\
474\end{array}$ & $\begin{array}{l}.709^{* *} \\
.000 \\
474\end{array}$ \\
\hline D4 & $\begin{array}{l}\text { Correlation Coefficient } \\
\text { Sig. (2-tailed) } \\
\mathrm{N}\end{array}$ & $\begin{array}{l}.524^{* * 4} \\
.000 \\
474 \\
\end{array}$ & $\begin{array}{l}.603^{3 * \pi} \\
.000 \\
474 \\
\end{array}$ & $\begin{array}{l}.613^{\text {**/ }} \\
.000 \\
474 \\
\end{array}$ & $\begin{array}{l}.643^{\text {** }} \\
.000 \\
474 \\
\end{array}$ & $\begin{array}{c}1 \\
.000 \\
474 \\
\end{array}$ & $\begin{array}{l}.648^{\text {** }} \\
.000 \\
474 \\
\end{array}$ & $\begin{array}{l}.633^{* *} \\
.000 \\
474 \\
\end{array}$ \\
\hline D6 & $\begin{array}{l}\text { Correlation Coefficient } \\
\text { Sig. (2- tailed) } \\
\text { N }\end{array}$ & $\begin{array}{l}.595^{* 67} \\
.000 \\
474\end{array}$ & $\begin{array}{l}.657^{* \cdots+} \\
.000 \\
474\end{array}$ & $\begin{array}{l}.660^{\text {अ*F }} \\
.000 \\
474\end{array}$ & $\begin{array}{l}.709^{\text {अ*F }} \\
.000 \\
474\end{array}$ & $\begin{array}{l}.633^{\text {*** }} \\
.000 \\
474\end{array}$ & $\begin{array}{c}.725^{\text {*स }} \\
.000 \\
474\end{array}$ & $\begin{array}{c}1 \\
.000 \\
474\end{array}$ \\
\hline
\end{tabular}

Correlation is significant at the 0.01 level (2-tailed).

Table 4 presents the findings of the Spearman Rank Correlation $\rho$ used to show the symmetric measures and the relationships between the variables. The positive relationship indicated in Spearman's @ p $<0.01$, as shown in Table 4, can, as Huysamen (1997) suggests, also be regarded as being statistically significant. The Spearman's correlation values, as indicated in Table 4 , are greater than 0 , indicating a positive correlation between the variables $\mathrm{B}$ and D1-6. Thus, a significant relationship exists amongst the variables. The correlation between D2 (confidence) and D3 (self-expression) is 0.248 with a significant p-value of 0 , which is less than 0.01 . There is a small correlation between D2 and D3, suggesting a slightly positive relationship between the confidence and self-expression behaviour of a leader. All other correlation values, as presented in Table 4, are within the range of 0.50 to 1.0, suggesting a strong relationship between the variables B and D1-D6. Therefore, a significant relationship exists between the variables with a highly significant $p-$ value of 0 , which is less than 0.01 . The correlation coefficients presented in Tables 3 and 4 are comparable to those presented in Tables 1 and 2 . They clearly show that the bivariate distribution of the two variables, the respondents' sense of job satisfaction, and their leaders' intrapersonal EIBs have a positive and significant relationship. Both Pearson $r$ and Spearman $\rho$ indicate that the two variables are significant and are therefore directly related. In other words, the more satisfied an employee is at work, the higher a leader's intrapersonal EIBs are likely to be. Conversely, the more dissatisfied an employee is at work, the lower a leader's intrapersonal EIBs are likely to be.

\section{Job Satisfaction}

The Pearson Correlation Coefficients ( $r$ ) of the variables; namely, the influence that a leader's interpersonal EIBs have on job satisfaction (E1-E6) and the interpersonal EIBs (C1-C6) are presented in Table 5. The findings of the Pearson's product moment coefficient (r) are used to show the symmetric measures and the relationships between the variables. The positive relationship indicated in Pearson's (r) @ p $<0.01$ and $<0.05$, as shown in Table 5 , is significant. 
Table 5: Pearson Correlation Coefficients For E1-E6 And C1-C6

\begin{tabular}{|c|c|c|c|}
\hline E1 & $\begin{array}{l}\text { Correlation Coefficient } \\
\text { Sig. (2-tailed) } \\
\text { N }\end{array}$ & $\begin{array}{l}.072 \\
.119 \\
474\end{array}$ & $\mathrm{C} 1$ \\
\hline E2 & $\begin{array}{l}\text { Correlation Coefficient } \\
\text { Sig. (2-tailed) } \\
\text { N }\end{array}$ & $\begin{array}{l}.149^{* *} \\
.001 \\
474\end{array}$ & $\mathrm{C} 2$ \\
\hline $\mathbf{E 3}$ & $\begin{array}{l}\text { Correlation Coefficient } \\
\text { Sig. (2-tailed) } \\
\text { N }\end{array}$ & $\begin{array}{l}.302^{* *} \\
.000 \\
474\end{array}$ & $\mathrm{C} 3$ \\
\hline E4 & $\begin{array}{l}\text { Correlation Coefficient } \\
\text { Sig. (2-tailed) } \\
\text { N }\end{array}$ & $\begin{array}{l}.104^{*} \\
.023 \\
474\end{array}$ & $\mathrm{C} 4$ \\
\hline E5 & $\begin{array}{l}\text { Correlation Coefficient } \\
\text { Sig. (2-tailed) } \\
\text { N }\end{array}$ & $\begin{array}{l}.247^{*+1} \\
.000 \\
474\end{array}$ & C5 \\
\hline E6 & $\begin{array}{l}\text { Correlation Coefficient } \\
\text { Sig. (2- tailed) } \\
\text { N }\end{array}$ & $\begin{array}{l}.211^{* *} \\
.000 \\
474\end{array}$ & C6 \\
\hline
\end{tabular}

** Correlation is significant at the 0.01 level (2-tailed).

* Correlation is significant at the 0.05 level (2-tailed).

The Spearman correlation $\rho$ of the employees' rating of their leaders' interpersonal EIBs (C1-C6) and their rating of how each of the interpersonal EIBs of their leader may influence their level of job satisfaction (E1-E6) are presented in Table 6. The positive relationship indicated in Spearman's @ $\mathrm{p}<0.01$ and $\mathrm{p}<0.05$, as shown in Table 6 , is significant.

Table 6: Spearman Correlation Coefficients ( $\rho$ ) For E 1 - 6 And C1 - 6

\begin{tabular}{|c|c|c|c|}
\hline E1 & $\begin{array}{l}\text { Correlation Coefficient } \\
\text { Sig. (2-tailed) } \\
\mathrm{N}\end{array}$ & $\begin{array}{l}.069 \\
.133 \\
474\end{array}$ & $\mathrm{C} 1$ \\
\hline E2 & $\begin{array}{l}\text { Correlation Coefficient } \\
\text { Sig. (2-tailed) } \\
\mathrm{N}\end{array}$ & $\begin{array}{l}.148^{* *} \\
.001 \\
474\end{array}$ & $\mathrm{C} 2$ \\
\hline E3 & $\begin{array}{l}\text { Correlation Coefficient } \\
\text { Sig. (2-tailed) } \\
\mathrm{N} \\
\end{array}$ & $\begin{array}{l}.310^{* * *} \\
.000 \\
474 \\
\end{array}$ & C3 \\
\hline $\mathrm{E} 4$ & $\begin{array}{l}\text { Correlation Coefficient } \\
\text { Sig. (2-tailed) } \\
\text { N }\end{array}$ & $\begin{array}{l}.113^{*} \\
.014 \\
474\end{array}$ & $\mathrm{C} 4$ \\
\hline E5 & $\begin{array}{l}\text { Correlation Coefficient } \\
\text { Sig. (2-tailed) } \\
\text { N }\end{array}$ & $\begin{array}{l}.246^{* * *} \\
.000 \\
474\end{array}$ & $\mathrm{C} 5$ \\
\hline E6 & $\begin{array}{l}\text { Correlation Coefficient } \\
\text { Sig. (2- tailed) } \\
\mathrm{N}\end{array}$ & $\begin{array}{l}.208^{* *} \\
.000 \\
474 \\
\end{array}$ & C6 \\
\hline
\end{tabular}

** Correlation is significant at the 0.01 level (2-tailed).

* Correlation is significant at the 0.05 level (2-tailed).

Table 7 presents the Pearson $\rho$ correlation coefficients of the variables - the respondents' rating of their leaders' intrapersonal EIBs (D1 - 6) and the respondents' ratings of how each of the intrapersonal EIBs of their leader may influence their level of job satisfaction (E7 - 12). The positive relationship indicated in Pearson's @ p $<$ 0.01 and $\mathrm{p}<0.05$, as shown in Table 7 , can be regarded as being significant. 
Table 7: Pearson Correlation Coefficients For E7 - 12 And D1 - 6

\begin{tabular}{|c|c|c|c|}
\hline E7 & $\begin{array}{l}\text { Correlation Coefficient } \\
\text { Sig. (2-tailed) } \\
\text { N }\end{array}$ & $\begin{array}{l}.069 \\
.133 \\
474\end{array}$ & D1 \\
\hline E8 & $\begin{array}{l}\text { Correlation Coefficient } \\
\text { Sig. (2-tailed) } \\
\text { N }\end{array}$ & $\begin{array}{l}.148^{\text {** }} \\
.001 \\
474\end{array}$ & D2 \\
\hline E9 & $\begin{array}{l}\text { Correlation Coefficient } \\
\text { Sig. (2-tailed) } \\
\text { N }\end{array}$ & $\begin{array}{l}.310^{* * 4} \\
.000 \\
474\end{array}$ & D3 \\
\hline E10 & $\begin{array}{l}\text { Correlation Coefficient } \\
\text { Sig. (2-tailed) } \\
\text { N }\end{array}$ & $\begin{array}{l}.113^{*} \\
.014 \\
474\end{array}$ & D4 \\
\hline E11 & $\begin{array}{l}\text { Correlation Coefficient } \\
\text { Sig. (2-tailed) } \\
\text { N }\end{array}$ & $\begin{array}{l}.246 \\
.000 \\
474\end{array}$ & D5 \\
\hline E12 & $\begin{array}{l}\text { Correlation Coefficient } \\
\text { Sig. (2- tailed) } \\
\text { N }\end{array}$ & $\begin{array}{l}.208^{* * *} \\
.000 \\
474\end{array}$ & D6 \\
\hline
\end{tabular}

Correlation is significant at the 0.01 level (2-tailed).

${ }^{*}$ Correlation is significant at the 0.05 level (2-tailed).

The Spearman rho, $\rho$ correlation of the respondents' rating of their leaders' intrapersonal EIBs (D1 - 6), and the respondents' ratings of how each of the intrapersonal EIBs of their leader influence their level of job satisfaction (E7 - 12) are presented in Table 8. The positive relationship indicated in Spearman's @ p $<0.01$ and p $<0.05$, as shown in Table 8 , is significant.

Table 8: Non-parametric Correlations Spearman's $\rho$ For E7 - 12 And D1 - 6

\begin{tabular}{|c|c|c|c|}
\hline E7 & $\begin{array}{l}\text { Correlation Coefficient } \\
\text { Sig. (2-tailed) } \\
\mathrm{N} \\
\end{array}$ & $\begin{array}{l}.138^{* *} \\
.003 \\
474 \\
\end{array}$ & D1 \\
\hline E8 & $\begin{array}{l}\text { Correlation Coefficient } \\
\text { Sig. (2-tailed) } \\
\text { N }\end{array}$ & $\begin{array}{l}.234^{* *+} \\
.000 \\
474\end{array}$ & D2 \\
\hline E9 & $\begin{array}{l}\text { Correlation Coefficient } \\
\text { Sig. (2-tailed) } \\
\text { N }\end{array}$ & $\begin{array}{l}.116^{*} \\
.011 \\
474 \\
\end{array}$ & D3 \\
\hline E10 & $\begin{array}{l}\text { Correlation Coefficient } \\
\text { Sig. (2-tailed) } \\
\text { N }\end{array}$ & $\begin{array}{l}.172 \\
.000 \\
474\end{array}$ & D4 \\
\hline E11 & $\begin{array}{l}\text { Correlation Coefficient } \\
\text { Sig. (2-tailed) } \\
\text { N }\end{array}$ & $\begin{array}{l}.143^{*} \\
.002 \\
474\end{array}$ & D5 \\
\hline E12 & $\begin{array}{l}\text { Correlation Coefficient } \\
\text { Sig. (2- tailed) } \\
\mathrm{N}\end{array}$ & $\begin{array}{l}.190^{* *} \\
.000 \\
474 \\
\end{array}$ & D6 \\
\hline
\end{tabular}

** Correlation is significant at the 0.01 level (2-tailed).

${ }^{*}$ Correlation is significant at the 0.05 level (2-tailed).

The correlation coefficients given in Tables 5-8 complete the final set of statistics required to meet the aims and objectives of the research. Both Pearson $r$ and Spearman $\rho$ indicate that the bivariate distribution of the variables, the employees' rating of their leaders' interpersonal and intrapersonal EIBs, and their rating of how each of their leaders' interpersonal and intrapersonal EIBs affect their sense of job satisfaction are significantly correlated. The correlation coefficients strongly suggest that there is a statistical significance between the respondents' level of job satisfaction, the rating of their leaders' EIBs, and how they believe a leader's EIBs would affect their sense of job satisfaction. Hence, all of the EIBs of leaders identified in this study can therefore be described as intervening variables that influence the employees' sense of job satisfaction. The number of responses that indicated each of the EIBs of a leader would have an influence on an employee's sense of job satisfaction ranged from $93 \%$ (a leader's sense of self-awareness) to $99 \%$ (a leader's ability to be adaptable). As the responses are significantly similar, it can be stated that the employees indicated that all the EIBs of their leaders would 
influence their sense of job satisfaction.

\section{CONCLUSION}

The findings of this research indicated that employees' expectations are that, in order for them to experience job satisfaction, their leaders need to demonstrate appropriate interpersonal and intrapersonal EIBs. Outstanding leadership EIBs can impact positively on employees' performance delivery and can be the precursor of their satisfaction and happiness in the workplace. It can therefore be concluded from the statistics of this exploratory study that there is a significant correlation between the sense of job satisfaction of employees and their leaders' interpersonal and intrapersonal EIBs. The findings strongly suggest that those employees who are satisfied at their place of work rate their leaders' interpersonal and intrapersonal EIBs as being high. Conversely, the findings indicate that those employees who are dissatisfied at their place of work rate their leaders' interpersonal EIBs and intrapersonal EIBs as being low. Evidently, in order to be satisfied and happy at work, the findings clearly indicated that employees need to be led by leaders who are confident in their leadership role, who send out clear unambiguous messages, who maintain self-control, who are adaptable and flexible, who face the future with optimism, and who support the establishment of a collegial environment. Undoubtedly, the EIBs of leaders have the potential for improving the job satisfaction of employees and can nurture a leadership style that forges strong relationships between leaders and their employees. More research needs to be undertaken on the effects of leaders' EIBs on the job satisfaction and happiness of their employees.

\section{AUTHOR INFORMATION}

Professor Prakash Singh is a professor of education at the Nelson Mandela Metropolitan University in Port Elizabeth, South Africa. He is currently a rated researcher by the National Research Foundation in South Africa, and is a former Senior Research Fulbright scholar. Professor Singh is the author of Innovative Strategies to Develop Better Schools and co-author of Principal Leadership. He has also published widely in peer reviewed journals, focusing on leadership and management, organisational effectiveness, emotional intelligence, tobephobia, and curriculum development. Professor Singh has presented numerous papers at international conferences. E-mail: Prakash.Singh@nmmu.ac.za

\section{REFERENCES}

1. Bar-On, R. (2000). Emotional and social intelligence: Insights from the emotional quotient inventory (EQi). In R. Bar-On \& J.D.A. Parker (Eds.), Handbook of emotional intelligence. San Francisco: Jossey-Bass.

2. Bass, B.M. (2002). Cognitive, social and emotional intelligence of transformational leaders. In R.E. Riggio \& S.E. Murphy (Eds.), Multiple intelligences and leadership. New York: LEA's Education Series.

3. Bazerghi, E. (2003a). Emotionally intelligent leadership. Retrieved from: www.humanperformancestrategies.com

4. $\quad$ Bazerghi, E. (2003b). Organizational effectiveness. Retrieved from: www.humanperformancestrategies.com

5. $\quad$ Birchfield, J. (2013). Empathy: A gateway to objectivity in leadership. Retrieved from: http://www.huffingtonpost.com/jan-birchfield-phd/empathy-business_b 2804056.html

6. Bouchikhi, H. \& Kimberly, J.H. (2000). The customized workplace. In S. Chowdhury (Ed.), Management 21C. London: Prentice Hall.

7. Boyatzis, R.E., Goleman, D. \& Rhee, K. (2000). Clustering competencies in emotional intelligence: Insights from the emotional competencies inventory (ECI). In R. Bar-On \& J.D.A. Parker (Eds.), Handbook of emotional intelligence. San Francisco: Jossey-Bass.

8. Cavallo, C. \& Brienza, M.A. (2001). Emotional competence and leadership excellence at Johnson \& Johnson: The emotional intelligence and leadership study. Corporate Consulting Group. Retrieved from: www.corconsultinggroup.com

9. Cherniss, C. \& Adler, M. (2000). Promoting emotional intelligence in organisations. Alexandria, VA: American Society for Training and Development.

10. Chowdhury, S. (Ed.). (2000). Management 21C. London: Pearson.

11. Conger, J.A. \& Kanungo, R.N. (1998). Charismatic leadership in organizations. California: Sage. 
12. Cooper, R. \& Sawaf, A. (1997). Executive EQ. Emotional intelligence in business. New York: Penguin.

13. Covey, S.R. (2004). The eighth habit. Sydney: Simon \& Schuster.

14. Dainty, P. \& Anderson, M. (2000). Mindsets for managers. In S. Chowdhury (Ed.), Management $21 C$. London: Prentice Hall.

15. Dantley, M.E. (2005). Moral leadership: shifting the management paradigm. In F.W. English (Ed.), The Sage handbook of educational leadership. California: Sage.

16. Du Plessis, A., Bouwer, C. \& Eloff, I. (2002). Leadership in the enhancement of learning opportunities for all learners. In L. Calitz, O.L. Fuglestad \& S. Lillejord S (Eds.), Leadership in Education. Sandown:

Heineman.

17. Evans, P.A.L. (2000). The dualistic leader: Thriving on paradox. In S. Chowdhury (Ed.), Management $21 C$. London: Prentice Hall.

18. Fehd, L. (2001). Emotional intelligence: An executive handbook. Austin: Good Pages.

19. Gardner, H. (1999). Intelligence reframed. New York: Basic Books.

20. Gardner, L. \& Stough, C. (2002). Examining the relationship between leadership and emotional intelligence in senior level managers. Leadership \& Organisational Development Journal, 23(2): 68-78.

21. Gardner, L. \& Stough, C. (2003). Assessing the relationship between workplace emotional intelligence, job satisfaction and organisational commitment. Australian Journal of Psychology, 55:530.

22. Garratt, B. (2000). The twelve organizational capabilities: valuing people at work. London: HarperCollins.

23. Goleman, D. (1996). Emotional intelligence. London: Bloomsbury.

24. Goleman, D. (1998). Working with emotional intelligence. New York: Bantam Books.

25. Hayward, R. (2003). A survey of morale among NAPTOSA members, 2002. Edusource, 41:1-10.

26. Hoppe, S. \& Speck, B. (2003). Identifying and nurturing potential academic leaders. New Directions for Higher Education, 124: 3-12.

27. Huysamen, G.K. (1997). Descriptive statistics for the social and behavioural sciences. Cape Town: Creda.

28. Kochan, K.F. \& Reed, J.C. (2005). Collaborative leadership, community building, and democracy in public education. In F.W. English (Ed.), The Sage handbook of educational leadership. California: Sage.

29. Kouzes, J.M. \& Posner, B.Z. (1995). The leadership challenge. San Francisco: Jossey-Bass.

30. Kouzes, J.M. \& Posner, B.Z. (2000). The Janusian leader. In S. Chowdhury (Ed.), Management 21C. London: Prentice Hall.

31. Kouzes, J.M. \& Posner, B.Z. (2001). Bringing leadership lessons from the past into the future. In W. Bennis, G.M. Spreitzer \& T.G. Cummings (Eds.), The future of leadership. San Francisco, California: Jossey-Bass.

32. Lee, Q. (2005). Leadership levels and issues. Lean briefing newsletter of Lean manufacturing strategy. www.strategosinc.com/leadership.

33. Levine, S.R. (2000). The value-based edu-leader. In S. Chowdhury (Ed.), Management 21C. London: Prentice Hall.

34. Liddy, S. (2013). Women and emotional intelligence: The new paradigm in business. Retrieved from: http://www.huffingtonpost.com/susan-liddy-ma-pcc-cpcc/women-and-emotional-intelligence.

35. Manser, P.G. (2005). The influence of school leaders' emotionally intelligent behaviours on the job satisfaction of employees in the Eastern Cape. PhD thesis. Port Elizabeth: Nelson Mandela Metropolitan University.

36. Maxwell, J.C. (1993). Developing the leader within you. Nashville: Thomas Nelson.

37. Mayer, J.D., Salovey, P. \& Caruso, D. (2000). Competing models of emotional intelligence. In R.J. Sterrenberg (Ed.), Handbook of emotional intelligence. New York: Cambridge University Press.

38. McMillan, J.H. \& Schumacher, S. (2001). Research in education. New York: Longman.

39. Noyes, B.R. (2003). Emotional Intelligence and Leadership. Leadership International. Retrieved from: www.leadershipinternational.com.

40. Orme, G. (2000). The developing world of emotional intelligence. Retrieved from: info@ ejuk.com.

41. Orme, G. (2001). Emotionally intelligent living. London: Crown House.

42. Orme, G. \& Cannon, K. (2000). Everything you wanted to know about implementing an emotional intelligence programme (but were afraid to ask). EQ Network. Retrieved from: www.Eiuk.com

43. Pascoe, C., Ali, I.M. \& Warne, L. (2002). Yet another role for job satisfaction and work motivation Enabler of knowledge creation and knowledge sharing. Insite, June: 39-48. 
44. Robson, C. (2002). Real world research: a resource for social scientists and practitioner-researchers. Oxford: Blackwell.

45. Salovey, P. \& Mayer, J.D. (1990). Emotional intelligence. Imagination, Cognition, and Personality, 9: 185211.

46. Salovey, P. \& Sluyter, D. (1997). Emotional development and emotional intelligence. New York: Basic Books.

47. Senge, P.M. \& Kaufer, K.H. (2000). Communities of leaders or no leadership at all. In S. Chowdhury (Ed.), Management 21C. London: Prentice Hall.

48. Sharon, M., Latour, U., Bradley, C. \& Hosmer, U. (2002). Emotional intelligence. Implications for all United States Air Force leaders. Air and Space Power, 16: 27-35.

49. Shoho, A.R., Merchant, B.M. \& Lugg, C.A. (2005). Social justice: seeking a common language. In F.W. English (Ed.), The Sage handbook of educational leadership. California: Sage.

50. Singh, P. (2005). Use of the collegial leadership model of emancipation to transform traditional management practices in secondary schools. South African Journal of Education, 25:11-18.

51. Singh, P. (2008). The effects of Tobephobia on learning outcomes in the educational milieu. International Journal of Learning, 15(3):10-15.

52. Singh, P. (2010). Innovative strategies to develop better schools. Sydney, Australia: Common Ground.

53. Singh, P. (2011). Tobephobia experienced by teachers in secondary schools: An exploratory study focusing on curriculum reform in the Nelson Mandela Metropole. Africa Education Review, 8(2): 372-388.

54. Singh, P. \& Manser, P. (2008). Correlation between the perceived emotionally intelligent interpersonal behaviours of school principals and the job satisfaction of their teachers. The International Journal of Knowledge, Culture \& Change Management, 8(1), 189-200.

55. Singh, P., Manser, P. \& Dali, C. (2013). Principal leadership: Interconnectedness between emotional intelligence, work-integrated learning competencies and collegial leaders. Saarbrucken, Germany: LAP LAMBERT Academic Publishing.

56. Spangenberg, H. (1994). Understanding and implementing performance management. Kenwyn: Juta.

57. Staw, B.M. (1996). Organisational psychology and the pursuit of the happy/productive worker. In M. Steers, L.W. Porter \& G.A. Bigley (Eds.), Motivation and leadership at work. Singapore: McGraw - Hill.

58. Stein, S. \& Book, H. (2001). The EQ edge. Emotional intelligence and your success. Toronto: Stoddart.

59. Sterrett, A.S. (2000). The manager's pocket guide to emotional intelligence. Massachusetts: HRD Press.

60. Strümpfer, D. J. W. \& Mlonzi, E. N. (2001). Antonovsky's sense of coherence scale and job attitudes: three studies. South African Journal of Psychology, 31, 31-54.

61. Vermeulen, S. (1999). EQ. Emotional intelligence for everyone. Rivonia: Zebra Press.

62. Yun, W. (1998). Successful employee motivation in China. Alta Vista: Regional Centre of Ngee Ann Polytechnic. 